\title{
LXII. On the change of colour in blue vegetable colours by metallic salts
}

\author{
Mr.J. Murray
}

To cite this article: Mr. J. Murray (1821) LXII. On the change of colour in blue vegetable colours by metallic salts, Philosophical Magazine Series 1, 58:282, 273-274, DOI:

10.1080/14786442108652624

To link to this article: http://dx.doi.org/10.1080/14786442108652624

里 Published online: 27 Jul 2009.

Submit your article to this journal $₫$

Џll Article views: 2

Q View related articles $\square$ 
Now, $\delta \mathrm{A}+\delta \mathrm{B}+\delta \mathrm{C}$, is the excess of the angles of the spherical triangle above those of the plane triangle, or above two right angles; and $\frac{s}{r^{2}}$ is the area of the spherical triangle on the sphere whose radius is unit; and, by the well known theorem of Albert Girard, these quantities are equal. Wherefore

$$
\delta \mathrm{A}+\delta \mathrm{B}+\delta \mathrm{C}-\frac{s}{r^{2}}=0
$$

consequently,

$$
\left(\delta A-\frac{s}{3 r^{2}}\right)(\tan A+\tan B+\tan C)=0 .
$$

Because $A+B+C=180, \tan C=-\tan (A+B)$; therefore, $\tan A+\tan B+\tan C=\tan A+\tan B-\tan (A+B), a$ quantity that in no circumstances can be equal to zero. Wherefore

and hence, by equat. (4),

$$
\delta \mathrm{A}-\frac{s}{3 r^{2}}=0
$$

$$
\begin{aligned}
\delta \mathrm{A} & =\frac{s}{3 r^{2}}, \\
\delta \mathrm{B} & =\frac{s}{3 r^{2}}, \\
\delta \mathrm{C} & =\frac{s}{3 r^{2}} .
\end{aligned}
$$

Consequently,

$$
\begin{aligned}
& \mathrm{A}=\mathrm{A}^{\prime}-\frac{s}{3 r^{2}}=\mathrm{A}^{\prime}-\frac{\delta \mathrm{A}+\delta \mathrm{B}+\delta \mathrm{C}}{3}, \\
& \mathrm{~B}=\mathrm{B}^{\prime}-\frac{s}{3 r^{2}}=\mathrm{B}^{\prime}-\frac{\delta \mathrm{A}+\delta \mathrm{B}+\delta \mathrm{C}}{3}, \\
& \mathrm{C}=\mathrm{C}^{\prime}-\frac{s}{3 r^{2}}=\mathrm{C}^{\prime}-\frac{\delta \mathrm{A}+\delta \mathrm{B}+\delta \mathrm{C}}{3}
\end{aligned}
$$

JIVOR Y.

LXII. On the Change of Colour in Blue vegetable Colours by metallic Salts. By Mr.J. Murnay.

$W_{\mathrm{E} \text { had rested quietly in the belief that the relations of acids }}$ and alkalis to vegetable colours were uniform; that the first class of bodies turned vegetable blues to red, or restored the original tint obliterated by an alkali; and that the seeond class, or alkalis, restored the blue colour changed to red by acids, or deepened the yellow and red obtained from turmeric, Brasil wood, \&c. into brown. It was at length discovered that boracic acid produced the same effect on turmeric as alkalis would do, and I further find that on tincture of cabbage, and syrup of violets, this peculiar characteristic is still maintained.

Vol. 58. No. 282. Oct.1821. . $\quad \mathrm{M}^{\prime} \mathrm{m}$ In 
In a series of experiments lately made on vegetable colours, 1 discovered the remarkable fact, that subacetate of lead, nitrate and sulphate of copper, nitromuriate of platinum, nitromuriate of gold, \&c. turned syrup of violets, tincture of cabbage, columbine, blue byacinth, \&c. green; and that when these colours are even reddened by acetic or citric or carbonic acid, \&c. the metallic solutions restore the original blue colour. Boracic acid reddens the yellow colour obtained from Reseda lut., and so do the metallic solutions.

It seems evident, therefore, that we have yet to learn the invariable characteristics of alkalis and acids. We may attempt to cover our ignorance by a free use of the term anomaly, but I do hold that in the universe of God there is no such thing as anomaly.

LXIII. On the Solar Eclipse of the 7th Septemler 1820; teing a Comparison of Calculations with some of the Olservations made in Great Britain and on the Continent. By Mr. Grorge INines.

\section{To Dr. Tilloch.}

$S_{I R},-I_{N}$ order to compare the observed with the computed times of the phænomena of the late solar eclipse, I have selected several of the observations which have appeared in your Magazine, and in the Edinburgh Philosophical Journal, and made the necessary calculations for the several places by the Tables of Delambre and Burckhardt. From these calculations it appears that the tables give the time of conjunction too early, and the moon's apparent semidiameter too great; as a less semidiameter would have made the errors of the tables, as deduced from the several observations, more uniform for the beginning and end.

The resnits obtained from the observations of the beginning and end at Gosport, and of the end at Padua, differ much from the rest. Perhaps some error has been committed in allowing for the errors of the clocks, or in transcribing. In calculating the time of the end for Plymouth, I have used the longitude given with the observation; but I observe that it is greater than any of those given in the Requisite 'Tables, as the result of accurate observations, for eight places in Plymouth.

It is not stated whether the instants of the last five observations are given in mean or apparent time, but from the calculations it would appear that they are given in mean time.

In making the calculations it will be found, that an error of $1^{\prime \prime}$ in the moon's semidiameter gives an error of about $2^{\prime \prime}, 98$, and 